\title{
Identification of Rice Blast Resistance Genes in South Central Coast of Vietnam Using Monogenic Lines under Field Condition and Pathogenicity Assays
}

\author{
Thuy Thi Thu Nguyen ${ }^{1,4}$, Hai Thi Hong Truong, ${ }^{2,4}$, Long Tien Nguyen ${ }^{1,4}$ and Linh Hoang Khanh Nguyen ${ }^{3,4}$ \\ 1. Department of Plant Protection, Faculty of Agronomy, College of Agriculture and Forestry, Hue University, 102 Phung Hung, \\ Hue City, Vietnam \\ 2. Department of Biotechnology, Faculty of Agronomy, College of Agriculture and Forestry, Hue University, 102 Phung Hung, Hue \\ City, Vietnam \\ 3. Department of Land Information Technology, Faculty of Land Resources and Agricultural Environment, College of Agriculture \\ and Forestry, Hue University, 102 Phung Hung, Hue City, Vietnam \\ 4. Hue University, 03 Le Loi, Hue City, Vietnam
}

\begin{abstract}
In the present study, the authors studied the interaction between 26 monogenic differentials carrying 26 blast resistance genes with 15 isolates of Pyricularia oryzae under field conditions and pathogenicity assays. The result in field conditions showed that area under disease progress curves (AUDPC) of monogenic lines was found to range from 0 to 142.3. Lijiangxintuanheigu (LTH) was susceptible in all of regions. The monogenic lines carrying Pik, Pik-p, Pik-h, Piz, Pi1, Pi7(t), Pik-m, Pi4(t), Pish, Pi9(t) and Pita were highly resistant to blast in all of regions. In plastic house net conditions, the percentage of virulent reactions of monogenic lines to 15 isolates was found to range from $23.1 \%$ to $84.6 \%$. LTH was susceptible to all 15 isolates. All 26 monogenic lines were resistant to at least 3 isolates of $P$. oryzae, and the frequency of resistant reactions of the monogenic lines carrying Pik, Pik-p, Pik-h, Piz, Pi4(t), Pish, Pi1, Pi7(t), Pi9, Pik-m and Pita were 80.0\%, 93.3\%, 93.3\%, 80.0\%, 73.3\%, 86.7\%, 73.3\%, 80.0\%, 80.0\%, 80.0\% and $80.0 \%$, respectively. These findings suggest that Pik, Pik-p, Pik-h, Piz, Pi4(t), Pish, Pi1, Pi7(t), Pi9, Pik-m and Pita may be important $R$ genes for preventing blast disease in South Central Vietnam. Based on these data, a useful strategy for managing rice blast disease by stacking pyramiding blast $R$ genes against pathogenic $P$. oryzae isolates at hotspot in South Central Coast of Vietnam was proposed.
\end{abstract}

Key words: Rice, $P$. oryzae, blast rice, monogenic lines, resistance genes.

\section{Introduction}

Rice (Oryza sativa L.) is one of the most important staple food crops for more than half of the world's population [1]. Rice blast, caused by Pyricularia oryzae Cav. (P. oryzae), is the most devastating rice disease that occurs all over the world [2]. The yield loss caused by blast vary widely depends on agro-systems and can reach several million tons, 10\% to $30 \%$ of crops [3]. Under certain environmental

Corresponding author: Thuy Thi Thu Nguyen, Ph.D., research fields: plant pathology and molecular plant pathology. conditions and cultural practices, 100\% loss was observed [4]. Cultural practices, fungicides and genetic resistance are interchangeably used among different rice production areas worldwide to prevent blast disease [5-8]. Extensive and uncontrolled use of fungicides poses a significant concern for human health and environmental safety. Hence, utilization of multiple $R$ genes with over lapped resistance spectra is one of the most powerful strategies for manage blast disease [9-11]. To date, 96 major blast $R$ genes and quantitative trait locus (QTLs) have been identified and mapped using DNA markers [12]; 18 of these 
genes have been cloned and used for crop protection [13]. However, the management of rice blast caused by $P$. oryzae through the use of disease resistant cultivars has become difficult because of the highly variable nature of the pathogen as well as favorable environmental conditions for infection during the crop season. The virulence of rice blast pathogen isolates in a population tends to shift from avirulence to virulence, rather than virulence to avirulence, on a given host [14]. Such variability has made it difficult to identify strategies for selecting or breeding rice cultivars that show durable resistance to blast populations in a given area. Most of the blast resistant cultivars of rice succumb to the disease within 2-3 years of their introduction into a disease-prone area $[15,16]$. Therefore, determining the effectiveness of blast $R$ genes in a certain area is important in assisting the development of rice breeding programs, which generate rice with long lasting effective genetic resistance [17].

The monogenic lines have been important assets to identify blast $R$ genes [18]. The first international rice blast differential system was developed in the 1960 to determine physiological races of $P$. oryzae [19]. Makill and Boman [20] developed a set of near-isogenic lines (NILs) derived from CO39 with 14 $R$ genes, including Pish, Pib, Piz-5, Pz-t, Pi5(t), Piks, Pik, Pik-h, Pik-m, Pik-p, Pi1, Pi7(t), Pita and Pita-2. In China, a set of NILs were developed with five blast $R$ genes Pib, Pik, Pik-m, Pik-p and Pita-2, using a susceptible japonica-type genetic background, Lijiangxintuanheigu (LTH) [21]. A set of monogenic lines, containing 24 major $R$ genes Pia, Pii, Pik, Pik-s, Pik-m, Pik-h, Pik-p, Piz, Piz-5, Piz-t, Pita, Pita-2, Pib, Pit, Pish, Pi1, Pi3, Pi5(t), Pi7, Pi9, Pi11, Pi12(t), $P i 19$ and $P i 20(t)$ in the blast-susceptible recurrent japonica variety LTH, were developed by the International Rice Research Institute (IRRI) [22]. This differential set is excellent materials that have been used to identify blast $R$ genes worldwide [12, 23].

In Vietnam, rice blast disease is one of the most destructive diseases limiting rice production, because the fungal pathogen can infect and cause lesions on almost all organs of the plant [24]. In 2012, the total area of infection rice blast disease was 366,412 ha, of which 11,400 ha are severe infections, 8 ha are full lost, and reduction in milling yield is about $10 \%-25 \%$ [25]. The South Central Vietnam is within the "hotspot" areas of Vietnamese rice. Blast disease has been found in more than 2,054 ha in South Central Vietnam [25]. Although the major blast genes Pita, $P i b$ and Pik-m are widely used, the effectiveness of these $R$ genes at Central Vietnam has not been determined yet.

The present study was conducted to evaluate disease reactions of selected field blast isolates on 26 monogenic differentials and provide useful information in formulating strategies for improving blast resistance.

\section{Materials and Methods}

\subsection{Plant Materials}

A set of blast differential varieties, consisting of 26 monogenic lines with 26 R genes (Pia, Pii, Pik-s, Pik, Pik-p, Pik-h, Piz, Pi2(t), Piz-t, Pi4(t), Pib, Pit, Pish, Pi1, Pi3, Pi5(t), Pi7(t), Pi9, Pi12(t), Pi19, Pik-m, Pi20, Pita2, Pita, Pi11(t) and Piz5) developed under IRRI were used. The recurrent parent was the blast-susceptible variety LTH, which was used as a susceptible control.

\subsection{Field Experiment}

\subsubsection{Experimental Design}

The experiment was conducted in farmer's field at the hotspot in Vietnam South Central Coast, including, Quang Nam (QN), Quang Ngai (QNG) and Binh Dinh (BD) province (Fig. 1). The chosen locations have a long history of strong blast disease presence and are mainly at poor alluvial soil.

The trial was laid down in a randomized complete block design. Each genotype was planted in two rows of $5 \mathrm{~m}$ long as an experimental unit to evaluate qualitative 


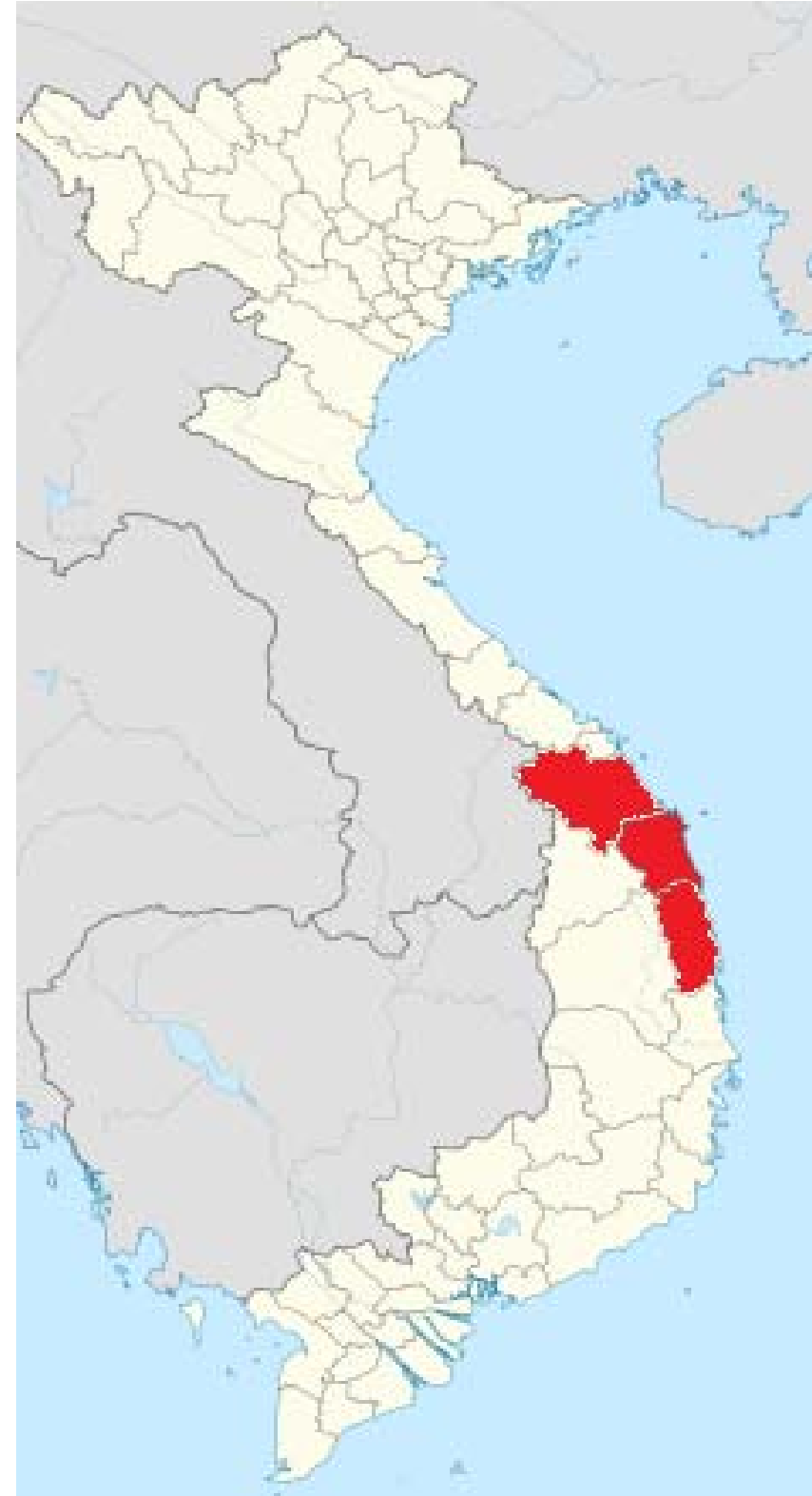

Fig. 1 Different location of field trials at South Central Vietnam.

resistance to blast; distance between rows was $20 \mathrm{~cm}$.

The fertilizers were applied at the rate of $100 \mathrm{~kg}, 50$ $\mathrm{kg}$ and $50 \mathrm{~kg}$ per ha of $\mathrm{N}, \mathrm{P}_{2} \mathrm{O}_{5}$ and $\mathrm{K}_{2} \mathrm{O}$, respectively. All $\mathrm{P}_{2} \mathrm{O}_{5}$ were used as basal at the time of sowing. The $30 \mathrm{~kg} \mathrm{~N}$ and $25 \mathrm{~kg} \mathrm{~K} \mathrm{~K}_{2} \mathrm{O}$ were uniformly broadcasted at 12 days after sowing (DAS), $40 \mathrm{~kg} \mathrm{~N}$ was used at 20 DAS and the rest on 45 DAS.

\subsubsection{Disease Assessment}

Ten plants were randomly (diagonally) selected from each plot $(4 \mathrm{~m} \times 2 \mathrm{~m})$ and tagged. Disease scoring started from the 15th day after seeding and periodic survey was made one time every seven days. The disease severity was calculated as disease severity (\%), calculated as Eq. (1):

Disease severity $(\%)=($ sum of all numerical rating $) /$

(total number of leaves or plants observed) $\times$ maximum rating $\times 100$

Disease assessment was scored based on the reaction of the differential varieties/cultivars. The lesions were scored as follows:

0 = no lesion observed;

$1=$ small brown specks off pinpoint size or large brown specks without sporulation center;

3 = small, roundish to slightly elongated necrotic sporulation spots, about 1-2 $\mathrm{mm}$ in diameter with a distinct brown margin or yellow halo;

5 = narrow or slightly elliptical lesions, $1-2 \mathrm{~mm}$ in breadth, more than $3 \mathrm{~mm}$ long with a brown margin;

7 = broad spindle-shaped lesion with yellow, brown, or purple margin;

9 = rapidly, coalescing small, whitish, grayish, or bluish lesions without distinct margins.

Symptom scores were attributed as average symptom observed in each experimental unit [26].

Area under disease progress curves (AUDPC) was calculated based on the Eq. (2) used by Das et al. [27]:

$$
\mathrm{AUDPC}=\sum_{i=1-(n-1)}\left[\left(Y_{i+1}+Y_{i} / 2\right) \times\left(t_{i+1}-t_{i}\right)\right]
$$

where $Y_{i}$ is percentage of disease at the ith observation, $t_{i}$ is time at the ith observation, and $n$ is total number of observation. AUDPC was calculated for each rice cultivar.

\subsection{Pathogenicity Assays}

2.3.1 Collection, Isolation and Culture Maintenance

A total of 200 samples of leave and panicle neck having blast rice symptom were collected from experimental fields of rice production areas of three provinces at South Central Vietnam (QN, QNG and BD) from 2014 to 2015. Single lesions were placed on glass rods in Petri dishes with wet filter paper and 
incubated at $25{ }^{\circ} \mathrm{C}$ until sporulation. With a pointed capillary tube, spores will be picked from a single lesion under dissecting microscope and spread onto water agar in Petri dishes. A single spore was transferred on potato dextrose agar slant under a dissecting microscope and incubated from $8 \mathrm{~d}$ to $10 \mathrm{~d}$ at $26^{\circ} \mathrm{C}$. For maintenance of the isolates obtained from single spore culture, the colony was grown in sterilized filter paper, which was put on potato dextrose agar and incubated for $10 \mathrm{~d}$. After that, only the paper pieces were transferred onto empty Petri plate for drying at $37{ }^{\circ} \mathrm{C}$ for $3 \mathrm{~d}$; after drying, they were stored in small bottle with silica gel in a freezer at $-10{ }^{\circ} \mathrm{C}$ [28]. List of blast isolates is presented in the Table 1.

\subsubsection{Test Cultivars}

Seedlings of 26 monogenic lines resistance to $P$. oryzae and one susceptible variety LTH were grown in the plastic house net in either plastic pots $(25 \times 25 \times$ $30 \mathrm{~cm}$ ) containing $4 \mathrm{~kg}$ of soil fertilized with N-P-K (20-20-10 g pot). Ten seeds of each line/cultivar were planted in a plastic pot. Plants were grown plastic house net at $25-30{ }^{\circ} \mathrm{C}$ for four weeks, until they reached the four leaf stage. The experiment was conducted in a randomized complete block design with three replications. Four-week-old plants (4-leaf

Table $1 P$. oryzae strains from center of Vietnam used in this study.

\begin{tabular}{lll}
\hline Isolate & Origin & Cultivar \\
\hline QN49 & Quang Nam & BC15 \\
QN95 & Quang Nam & Xi23 \\
QN125 & Quang Nam & OM4900 \\
QN186 & Quang Nam & SV181 \\
QN239 & Quang Nam & KD18 \\
QNG63 & Quang Ngai & Thom 1 \\
QNG109 & Quang Ngai & KD18 \\
QNG158 & Quang Ngai & Q5 \\
QNG193 & Quang Ngai & BC15 \\
QNG249 & Quang Ngai & Thom 1 \\
BD38 & Binh Dinh & BC15 \\
BD92 & Binh Dinh & Q5 \\
BD128 & Binh Dinh & KD28 \\
BD183 & Binh Dinh & BC15 \\
BD258 & Binh Dinh & KD28 \\
\hline
\end{tabular}

stage) were inoculated with spore suspensions as described in the study of Berruyer et al. [29].

\subsubsection{Inoculation and Disease Assessment}

Five strains of $P$. oryzae selected in each province were used as representative monoconidial isolates for the present study. Four-week-old plants at the 4-5 leaf stage in each pot were inoculated by spraying $20 \mathrm{~mL}$ aqueous spore suspension $\left(1 \times 10^{5}\right.$ spores $\left./ \mathrm{mL}\right)$ onto the leaves. Disease reactions were scored at the 7 th days after inoculation on a scale from 0 to 5 , in which $0=$ no evidence of infection; 1 = brown specks smaller than $0.5-1 \mathrm{~mm}$ in diameter; $3=$ roundish to elliptical lesions about 1-3 $\mathrm{mm}$ in diameter with gray centers and brown margins; 4 = typical spindle-shaped blast lesion, $3 \mathrm{~mm}$ or longer with little or no coalescence of lesions; $5=$ same as 4 , but half of one or more leaves killed by coalescence of lesions. Plants rated 0-3 were considered resistant, and those rated 4-5 were considered susceptible [20, 30]. For blast screening, the scores of five plants for each line were averaged and an actual infection means scales was used in analysis.

\section{Results}

\subsection{Field Experiments}

Table 2 showed AUDPC of leaf disease severity in the different monogenic line and at the different regions of the study. AUDPC figures varied among the different cultivars and were different for the three regions.

With respect to AUDPC of leaf disease severity, LTH (susceptible control) showed the highest percentage of spots, ranged from $203.8 \%$ to $352.6 \%$, of which the highest is at BD province and the lowest at QN province. LTH was followed by the lines containing $R$ genes: Pia, Pii, Pik-s, Piz-t, Pib, Pit, Pi12(t), Pi11(t), Pi3, Piz5 and Pi20(t) which showed high disease severity in all of regions, with values ranging between $24.3 \%$ and $142.3 \%$. However, in each location, a single blast $R$ gene can be effective in preventing blast disease, for example, $P i b$ and Piz- $t$ in 
Table 2 AUDPC for monogenic lines resistance to $P$. oryzae in the field of Central Vietnam during the spring season of 2014.

\begin{tabular}{|c|c|c|c|c|}
\hline \multirow{2}{*}{ Rice line } & \multirow{2}{*}{ Gene name } & \multicolumn{3}{|c|}{ AUDPC (\%) } \\
\hline & & Quang Nam & Quang Ngai & Binh Dinh \\
\hline IRBLa-A & Pia & 104.6 & 142.3 & 105.3 \\
\hline IRBLi-F5 & $P i i$ & 98.3 & 91.3 & 95.2 \\
\hline IRBLks-F5 & Pik-s & 93.2 & 132.7 & 92.7 \\
\hline IRBLk-ka & $P i k$ & 0.0 & 0.0 & 0.0 \\
\hline IRBLkp-K60 & Pik-p & 0.0 & 0.0 & 0.0 \\
\hline IRBLkh-K3 & Pik-h & 0.0 & 0.0 & 0.0 \\
\hline IRBLz-Fu & Piz & 0.0 & 0.0 & 0.0 \\
\hline IRBLz5-CA & $P i 2(t)$ & 78.1 & 72.4 & 0.0 \\
\hline IRBLzt-T & Piz-t & 104.2 & 94.2 & 0.0 \\
\hline IRBLta-K1 & $\operatorname{Pi4}(t)$ & 28.4 & 15.8 & 19.5 \\
\hline IRBLb-B & $P i b$ & 77.3 & 82.5 & 0.0 \\
\hline IRBLt-K59 & Pit & 95.4 & 92.5 & 60.4 \\
\hline IRBLsh-S & Pish & 19.4 & 21.6 & 18.5 \\
\hline IRBL1-CL & Pi1 & 0.0 & 0.0 & 0.0 \\
\hline IRBL3-CP4 & Pi3 & 64.2 & 68.3 & 94.6 \\
\hline IRBL5-M & $P i 5(t)$ & 28.4 & 82.4 & 0.0 \\
\hline IRBL7-M & $\operatorname{Pi7}(t)$ & 0.0 & 0.0 & 0.0 \\
\hline IRBL9-W & $\operatorname{Pi9}(t)$ & 29.3 & 27.3 & 32.4 \\
\hline IRBL12-M & $\operatorname{Pi12}(t)$ & 95.2 & 87.2 & 24.3 \\
\hline IRBL19-A & Pi19 & 62.4 & 68.3 & 31.5 \\
\hline IRBLkm-Ts & Pik-m & 0.0 & 0.0 & 0.0 \\
\hline IRBL20-IR24 & $P i 20(t)$ & 97.3 & 132.8 & 57.3 \\
\hline IRBLta2-Pi & Pita2 & 74.3 & 72.5 & 0.0 \\
\hline IRBLta-CP1 & Pita & 22.4 & 19.3 & 0.0 \\
\hline IRBL11-Zh & $\operatorname{Pi11}(t)$ & 123.7 & 27.6 & 48.5 \\
\hline IRBLz5-CA & Piz5 & 101.7 & 123.8 & 112.9 \\
\hline LTH & & 203.8 & 310.4 & 352.6 \\
\hline
\end{tabular}

$\mathrm{BD}$ region. The cultivars that showed medium susceptibility were Pi2(t), Pi19, Pita2 and Pi5(t) with values ranging from $31.5 \%-82.4 \%$. Among them, blast $R$ genes are still effective in preventing blast disease in some regions, such as $\mathrm{Pi2}(t), \mathrm{Pi5}(t)$ and Pita2 in BD province (Table 2). Pi4(t), Pish, Pi9(t) and Pita showed significantly resistance to $P$. oryzae. The highly resistant level to leaf blast in both two season and at all regions was observed in the monogenic lines carrying Pik, Pik-p, Pik-h, Piz, Pi1, $P i 7(t)$ and $P i k-m$ which with value of zero. This result suggested that effective genes for blast resistance in rice production areas in South Central Vietnam included Pik, Pik-p, Pik-h, Piz, Pi1, Pi7(t), Pik-m, Pi4(t), Pish, Pi9(t) and Pita.

\subsection{Pathogenicity Assays}

\subsubsection{Evaluation of Useful Blast $R$ Genes}

All monogenic lines were resistant to at least one isolate, indicating that the $R$ genes they carry will have some impact in preventing blast disease. However, the recurrent parent LTH was susceptible to all tested isolated. Among 26 monogenic lines, monogenic lines carrying Pik, Pik-p, Pik-h, Piz, Pi4(t), Pish, Pi1, Pi7(t), Pi9, Pik-m and Pita showed strong resistance, with the percentages of resistant reactions were $80.0 \%$, 93.3\%, 93.3\%, 80.0\%, 73.3\% 86.7\%, 73.3\%, 80.0\%, 80.0\%, $80.0 \%$ and $80.0 \%$, respectively (Fig. 2). These results suggest that Pik, Pik-p, Pik-h, Piz, Pi4(t), Pish, Pi1, Pi7(t), Pi9, Pik-m and Pita are highly effective against blast disease in South Central Vietnam. Furthermore, 


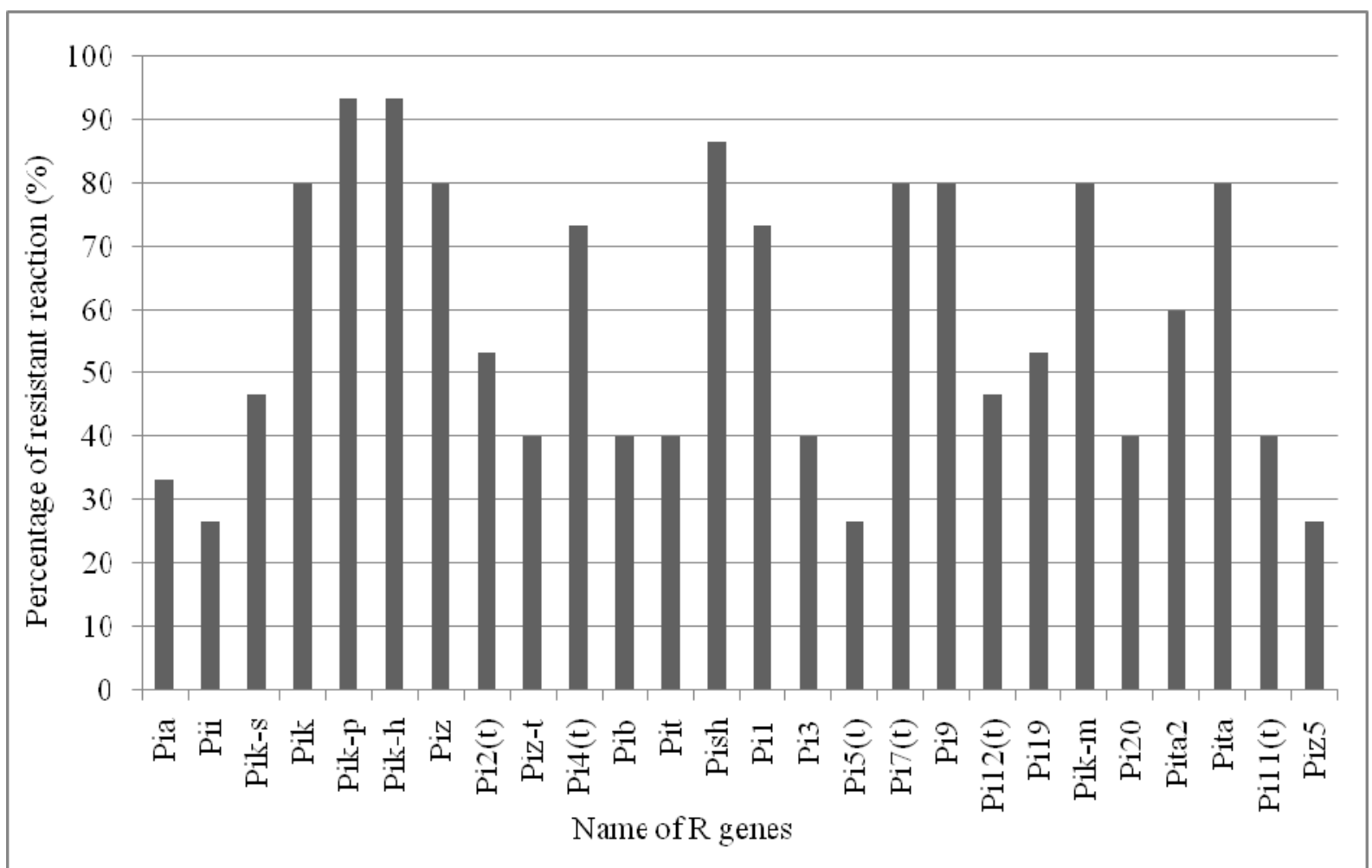

Fig. 2 Percentage of the resistant reaction of 26 monogenic lines containing an $R$ gene to isolates of $P$. oryzae.

in each location, a single blast $R$ gene can be effective in preventing blast disease. $P i k-h$ in QN province; Pik-p and Pish in QNG province and Pik, Pik-p, Piz, Pk-h, Pi4(t), Pish, Pi1, Pi7(t), Pi9, Pik-m, Pita2 and Pita in BD province may be adequate to prevent blast disease (Table 3). This result is similar to the result of experiments in the field.

\subsubsection{Virulence of $P$. oryzae Isolates}

All isolates were virulent to one or more monogenic lines. The frequency of virulence was found to be from $23.1 \%$ to $84.6 \%$. The frequency of virulence for isolate BD92 and BD258 was the lowest, which was 23.1\%, and the greatest was QN186 which was 84.6\% (Fig. 3). Overall, one or two isolates in each region were very virulent on the tested monogenic lines with $R$ genes. Notably, the pathogenicity of isolates from QN province was higher than those of the isolates in the other province (Table 3). The most virulent isolates (QN186) also were found in the QN province.

\subsubsection{A Strategy for Pyramiding Blast $R$ Genes}

In the present study, monogenic differentials carrying 26 major blast $R$ genes (Pia, Pii, Pik-s, Pik, Pik-p, Pik-h, Piz, Pi2(t), Piz-t, Pi4(t), Pib, Pit, Pish, Pi1, Pi3, Pi5(t), Pi7(t), Pi9, Pi12(t), Pi19, Pik-m, Pi20, Pita2, Pita, Pi11(t) and Piz5) were used to test the efficacy of resistance to 15 isolates from three provinces of South Central Vietnam. As a result, it can be better understand the resistance mediated by a specific $R$ gene. Such as, the monogenic variety carrying the Pi4(t) gene was demonstrated to prevent infections by $P$. oryzae isolates in the $\mathrm{BD}$ rice growing regions, but not in the QN and QNG region. In addition, it was able to identify the effective major $R$ gene(s) for different rice growing regions. Based on disease reactions, it is proposed that Pik, Pik-p, Pik-h, Piz, Pi4(t), Pi1, Pi7(t), Pi9, Pish, Pik-m and Pita can be used as $R$ gene donors for improved blast resistance in South Central Vietnam (Fig. 2). Futhemore, Pik-p and Pik-h appear to be resistant to most isolates and can be used as these blast $R$ genes to aid in breeding rice variety resistance of blast disease in South Central Vietnam. A combination of Pik-p or Pik-h with one of 
Table 3 Disease reaction of 26 rice monogenic lines with 15 isolates of $P$. oryzae.

\begin{tabular}{|c|c|c|c|c|c|c|c|c|c|c|c|c|c|c|c|c|c|}
\hline$R$ genes & $\begin{array}{l}\text { QN } \\
49\end{array}$ & $\begin{array}{l}\text { QN } \\
95\end{array}$ & $\begin{array}{l}\text { QN } \\
125\end{array}$ & $\begin{array}{l}\text { QN } \\
186\end{array}$ & $\begin{array}{l}\text { QN } \\
239\end{array}$ & $\begin{array}{l}\text { QNG } \\
63\end{array}$ & $\begin{array}{l}\text { QNG } \\
109\end{array}$ & $\begin{array}{l}\text { QNG } \\
158\end{array}$ & $\begin{array}{l}\text { QNG } \\
193\end{array}$ & $\begin{array}{l}\text { QNG } \\
249\end{array}$ & $\begin{array}{l}\text { BD } \\
38\end{array}$ & $\begin{array}{l}\text { BD } \\
92\end{array}$ & $\begin{array}{l}\text { BD } \\
128\end{array}$ & $\begin{array}{l}\text { BD } \\
183\end{array}$ & $\begin{array}{l}\text { BD } \\
258\end{array}$ & $\begin{array}{l}\text { Amount of } \\
\text { incompatible } \\
\text { isolates }\end{array}$ & $\begin{array}{l}\text { Percent of } \\
\text { incompatible } \\
\text { isolates (\%) }\end{array}$ \\
\hline Pia & $\mathrm{R}$ & S & S & $\mathrm{R}$ & S & $\mathrm{S}$ & $\mathrm{R}$ & S & S & S & S & S & $\mathrm{R}$ & S & $\mathrm{R}$ & 5 & 33.3 \\
\hline Pii & S & S & S & $\mathrm{S}$ & $\mathrm{S}$ & $\mathrm{S}$ & S & $\mathrm{R}$ & S & $\mathrm{R}$ & S & $\mathrm{R}$ & S & $\mathrm{S}$ & $\mathrm{R}$ & 4 & 26.7 \\
\hline Pik-s & $\mathrm{S}$ & $\mathrm{R}$ & S & S & $\mathrm{R}$ & S & $\mathrm{R}$ & S & $\mathrm{R}$ & $\mathrm{S}$ & $\mathrm{R}$ & S & $\mathrm{R}$ & $\mathrm{R}$ & S & 7 & 46.7 \\
\hline$P i k$ & $\mathrm{~S}$ & $\mathrm{R}$ & $\mathrm{R}$ & $S$ & $\mathrm{R}$ & $\mathrm{R}$ & $\mathrm{R}$ & $\mathrm{R}$ & $\mathrm{R}$ & $S$ & $\mathrm{R}$ & $\mathrm{R}$ & $\mathrm{R}$ & $\mathrm{R}$ & $\mathrm{R}$ & 12 & 80.0 \\
\hline Pik-p & $\mathrm{R}$ & $\mathrm{R}$ & $\mathrm{R}$ & S & $\mathrm{R}$ & $\mathrm{R}$ & $\mathrm{R}$ & $\mathrm{R}$ & $\mathrm{R}$ & $\mathrm{R}$ & $\mathrm{R}$ & $\mathrm{R}$ & $\mathrm{R}$ & $\mathrm{R}$ & $\mathrm{R}$ & 14 & 93.3 \\
\hline Pik-h & $\mathrm{R}$ & $\mathrm{R}$ & $\mathrm{R}$ & $\mathrm{R}$ & $\mathrm{R}$ & $\mathrm{R}$ & $\mathrm{R}$ & $\mathrm{R}$ & $\mathrm{R}$ & $\mathrm{S}$ & $\mathrm{R}$ & $\mathrm{R}$ & $\mathrm{R}$ & $\mathrm{R}$ & $\mathrm{R}$ & 14 & 93.3 \\
\hline Piz & $\mathrm{R}$ & $\mathrm{R}$ & $\mathrm{R}$ & S & $\mathrm{S}$ & $\mathrm{R}$ & $\mathrm{R}$ & $\mathrm{R}$ & $\mathrm{R}$ & S & $\mathrm{R}$ & $\mathrm{R}$ & $\mathrm{R}$ & $\mathrm{R}$ & $\mathrm{R}$ & 12 & 80.0 \\
\hline$P i 2(t)$ & $\mathrm{S}$ & $\mathrm{R}$ & $\mathrm{S}$ & S & $\mathrm{R}$ & $\mathrm{R}$ & $\mathrm{S}$ & S & S & $\mathrm{R}$ & $\mathrm{R}$ & S & $\mathrm{R}$ & $\mathrm{R}$ & S & 8 & 53.3 \\
\hline Piz-t & S & $\mathrm{R}$ & S & S & $\mathrm{R}$ & $\mathrm{R}$ & S & S & $\mathrm{R}$ & S & S & $\mathrm{R}$ & S & $\mathrm{S}$ & $\mathrm{R}$ & 6 & 40.0 \\
\hline $\operatorname{Pi4}(t)$ & S & $\mathrm{S}$ & $\mathrm{R}$ & $\mathrm{R}$ & $\mathrm{R}$ & $\mathrm{R}$ & $\mathrm{S}$ & $\mathrm{R}$ & $\mathrm{R}$ & S & $\mathrm{R}$ & $\mathrm{R}$ & $\mathrm{R}$ & $\mathrm{R}$ & $\mathrm{R}$ & 11 & 73.3 \\
\hline$P i b$ & $\mathrm{R}$ & $\mathrm{S}$ & $\mathrm{S}$ & S & $\mathrm{S}$ & $\mathrm{S}$ & $\mathrm{R}$ & $\mathrm{S}$ & $\mathrm{S}$ & $\mathrm{S}$ & $\mathrm{R}$ & $\mathrm{R}$ & $\mathrm{R}$ & $\mathrm{R}$ & S & 6 & 40.0 \\
\hline Pit & $\mathrm{S}$ & $\mathrm{S}$ & $\mathrm{R}$ & $\mathrm{S}$ & $\mathrm{S}$ & $\mathrm{R}$ & $\mathrm{S}$ & S & $\mathrm{S}$ & $\mathrm{R}$ & $\mathrm{S}$ & $\mathrm{R}$ & $\mathrm{S}$ & $\mathrm{R}$ & $\mathrm{R}$ & 6 & 40.0 \\
\hline Pish & S & $\mathrm{R}$ & $\mathrm{R}$ & $\mathrm{R}$ & $\mathrm{S}$ & $\mathrm{R}$ & $\mathrm{R}$ & $\mathrm{R}$ & $\mathrm{R}$ & $\mathrm{R}$ & $\mathrm{R}$ & $\mathrm{R}$ & $\mathrm{R}$ & $\mathrm{R}$ & $\mathrm{R}$ & 13 & 86.7 \\
\hline Pi1 & $\mathrm{R}$ & $\mathrm{S}$ & $\mathrm{R}$ & $\mathrm{S}$ & $\mathrm{S}$ & $\mathrm{R}$ & $\mathrm{R}$ & $\mathrm{R}$ & $\mathrm{R}$ & $\mathrm{S}$ & $\mathrm{R}$ & $\mathrm{R}$ & $\mathrm{R}$ & $\mathrm{R}$ & $\mathrm{R}$ & 11 & 73.3 \\
\hline Pi3 & $\mathrm{S}$ & $\mathrm{S}$ & $\mathrm{S}$ & $\mathrm{S}$ & $\mathrm{S}$ & $\mathrm{R}$ & $\mathrm{R}$ & $\mathrm{S}$ & $\mathrm{S}$ & S & $\mathrm{R}$ & $\mathrm{R}$ & $\mathrm{R}$ & $\mathrm{R}$ & S & 6 & 40.0 \\
\hline$P i 5(t)$ & $\mathrm{S}$ & $\mathrm{S}$ & $\mathrm{R}$ & $\mathrm{R}$ & $\mathrm{S}$ & $\mathrm{S}$ & $\mathrm{R}$ & S & $\mathrm{S}$ & S & $\mathrm{S}$ & $\mathrm{S}$ & $\mathrm{R}$ & $\mathrm{S}$ & $\mathrm{S}$ & 4 & 26.7 \\
\hline $\operatorname{Pi7}(t)$ & $\mathrm{R}$ & $\mathrm{S}$ & $\mathrm{R}$ & $\mathrm{S}$ & $\mathrm{R}$ & $\mathrm{R}$ & $\mathrm{R}$ & $\mathrm{R}$ & $\mathrm{R}$ & S & $\mathrm{R}$ & $\mathrm{R}$ & $\mathrm{R}$ & $\mathrm{R}$ & $\mathrm{R}$ & 12 & 80.0 \\
\hline Pi9 & $\mathrm{R}$ & $\mathrm{R}$ & $\mathrm{R}$ & S & $\mathrm{S}$ & $\mathrm{R}$ & $\mathrm{R}$ & $\mathrm{R}$ & $\mathrm{S}$ & $\mathrm{R}$ & $\mathrm{R}$ & $\mathrm{R}$ & $\mathrm{R}$ & $\mathrm{R}$ & $\mathrm{R}$ & 12 & 80.0 \\
\hline $\operatorname{Pi12}(t)$ & S & $\mathrm{S}$ & $\mathrm{R}$ & S & $\mathrm{R}$ & $\mathrm{R}$ & $\mathrm{S}$ & S & $\mathrm{R}$ & $\mathrm{S}$ & $\mathrm{S}$ & $\mathrm{R}$ & $\mathrm{R}$ & $\mathrm{S}$ & $\mathrm{R}$ & 7 & 46.7 \\
\hline Pi19 & $\mathrm{S}$ & $\mathrm{R}$ & $\mathrm{R}$ & S & $\mathrm{S}$ & $\mathrm{S}$ & $\mathrm{R}$ & S & $\mathrm{R}$ & $\mathrm{R}$ & $\mathrm{S}$ & $\mathrm{R}$ & $\mathrm{S}$ & $\mathrm{R}$ & $\mathrm{R}$ & 8 & 53.3 \\
\hline Pik-m & $\mathrm{R}$ & $\mathrm{R}$ & S & S & $\mathrm{R}$ & $\mathrm{R}$ & $\mathrm{R}$ & $\mathrm{R}$ & $\mathrm{R}$ & S & $\mathrm{R}$ & $\mathrm{R}$ & $\mathrm{R}$ & $\mathrm{R}$ & $\mathrm{R}$ & 12 & 80.0 \\
\hline Pi20 & $\mathrm{S}$ & $\mathrm{R}$ & $\mathrm{S}$ & S & $\mathrm{R}$ & $\mathrm{S}$ & $\mathrm{S}$ & S & $\mathrm{R}$ & $\mathrm{R}$ & $\mathrm{R}$ & S & S & $\mathrm{R}$ & $\mathrm{S}$ & 6 & 40.0 \\
\hline Pita2 & $\mathrm{S}$ & $\mathrm{S}$ & $\mathrm{R}$ & S & $\mathrm{R}$ & $\mathrm{R}$ & $\mathrm{S}$ & $\mathrm{S}$ & $\mathrm{R}$ & $\mathrm{S}$ & $\mathrm{R}$ & $\mathrm{R}$ & $\mathrm{R}$ & $\mathrm{R}$ & $\mathrm{R}$ & 9 & 60.0 \\
\hline Pita & $\mathrm{R}$ & $\mathrm{R}$ & $\mathrm{R}$ & $\mathrm{S}$ & $\mathrm{R}$ & $\mathrm{R}$ & S & $\mathrm{R}$ & $\mathrm{R}$ & S & $\mathrm{R}$ & $\mathrm{R}$ & $\mathrm{R}$ & $\mathrm{R}$ & $\mathrm{R}$ & 12 & 80.0 \\
\hline $\operatorname{Pi11}(t)$ & S & S & $\mathrm{R}$ & S & $\mathrm{R}$ & $\mathrm{S}$ & $\mathrm{R}$ & S & $\mathrm{R}$ & S & $\mathrm{S}$ & $\mathrm{R}$ & $\mathrm{S}$ & S & $\mathrm{R}$ & 6 & 40.0 \\
\hline Piz5 & $\mathrm{S}$ & $\mathrm{S}$ & $\mathrm{S}$ & $\mathrm{S}$ & $\mathrm{R}$ & $\mathrm{S}$ & $\mathrm{R}$ & $\mathrm{S}$ & $\mathrm{S}$ & $\mathrm{S}$ & $\mathrm{S}$ & $\mathrm{S}$ & $\mathrm{R}$ & $\mathrm{S}$ & $\mathrm{R}$ & 4 & 26.7 \\
\hline $\begin{array}{l}\text { Number of } \\
\text { virulence } \\
\text { isolates }\end{array}$ & 16 & 12 & 10 & 22 & 10 & 9 & 9 & 14 & 9 & 19 & 9 & 6 & 8 & 7 & 6 & & \\
\hline $\begin{array}{l}\text { Percent of } \\
\text { virulence } \\
\text { isolates (\%) }\end{array}$ & 61.5 & 46.2 & 38.5 & 84.6 & 38.5 & 34.6 & 34.6 & 53.8 & 34.6 & 73.1 & 34.6 & 23.1 & 30.8 & 26.9 & 23.1 & & \\
\hline
\end{tabular}

the genes (Pik, Piz, Pi4(t), Pi1, Pi7(t), Pi9, Pik-m and Pita) can also be effective in preventing blast infections in South Central Vietnam (Table 3).

\section{Discussion}

In Vietnam, rice blast disease is managed by the use of resistance genes in combination with seed treatments with systemic fungicides and fungicidal foliar sprays. The use of host resistance has proven to be the most effective and economical method for controlling rice blast $[11,31]$. It is necessary to know that host resistance, pathogenicity characteristics, including degree of pathogenicity, sporulation and spectrum of pathogenicity and environmental conditions are the critical factors determining the degree of plant disease [2]. The key step of controlling disease is to know interaction between host resistance and the pathogen. Evaluation of rice germplasm and breeding lines with the selected isolates have been realized worldwide.

The different progenies from various crosses showed the different level of blast disease reaction. Such differential defense responses result from the interaction of dominant and resistant $(R)$ gene of host 


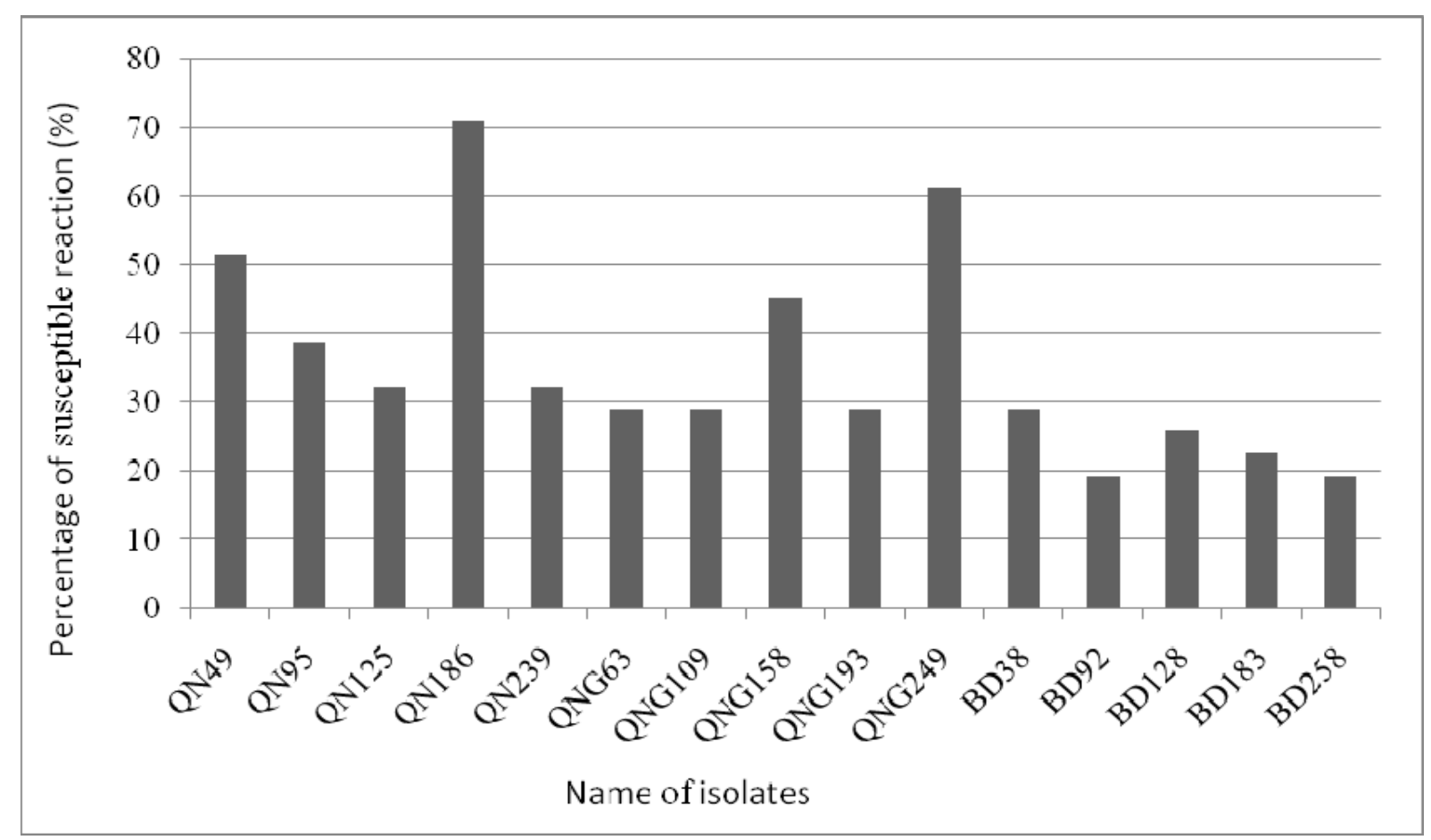

Fig. 3 Virulence frequency of the $15 P$. oryzae isolates.

and avirulence (AVR) genes of pathogen as proposed gene-for-gene hypothesis [32]. In rice, the interaction between host plant and pathogen $P$. oryzae is well documented as gene-for-gene system [6]. The resistance and susceptible interaction on rice conferred by single amino acid substitution in Pi-ta leucine rich domain (LRD) or in the AVR-Pi-ta protease motif, result in loss of resistant in plant. Thus, the different genetic of rice lines used in this study showed different interaction host resistance and pathogen blast rice in South Central Vietnam.

In this study, the differential system consisting of 26 differential $R$ genes and a universal susceptible LTH were used for rapid identification of the resistance spectra of $R$ genes in field condition and greenhouse conditions in South Central Vietnam. Inoculation and evaluation were repeated three times, and the disease reaction of each variety was based on a standard of IRRI [26] and the method of Bastiaans [30]. The authors' results suggest that Pik, Pik-p, Pik-h, Piz, Pi4(t), Pi1, Pi7(t), Pish, Pi9, Pik-m and Pita are the most effective blast $R$ genes in South Central Vietnam.
In the present study, 15 isolates were selected to represent the genetic diversity of rice blast populations at South Central Vietnam. Therefore, these results should provide a systematic way to map $R$ genes in breeding parents and assist in the development of appropriate breeding strategies for achieving effective management of the blast disease. To our knowledge, this was the first identification of blast $R$ genes for rice breeding in a specific rice growing area in South Central Vietnam.

\section{Conclusions}

Among 26 monogenic lines carrying $26 R$ genes evaluated on farmers field condition, seven monogenic lines containing genes Pik, Pik-p, Pik-h, Piz, Pi1, Pi7 (t) and Pik-m are highly resistant, four lines (Pi4(t), Pish, Pi9(t) and Pita) are moderately resistant, four lines are moderately susceptible and 11 lines were susceptible. Similarly, on greenhouse condition, 10 monogenic lines carrying genes $P i k$, Pik-p, Pik-h, Piz, Pi4(t), Pish, Pi1, Pi7(t), Pi9, Pik-m and Pita were high resistant with the percentages of resistant reactions were $80.0 \%$, 93.3\%, 93.3\%, 80.0\%, 
$73.3 \% 86.7 \%, 73.3 \%, 80.0 \%, 80.0 \%, 80.0 \%$ and $80.0 \%$, respectively. These findings suggest that $P i k$, Pik-p, Pik-h, Piz, Pi4(t), Pish, Pi1, Pi7(t), Pi9, Pik-m and Pita may be useful for preventing blast disease in South Central Vietnam. A concerted effort should be made to incorporate these effective genes into adapted backgrounds and to develop gene combinations that can provide broad-based durable resistance to blast rice.

\section{Acknowledgments}

The authors would like to express their sincere thanks to Vietnam National Foundation for Science and Technology Development (NAFOSTED) for supporting research grant No. 106-NN.02-2014.12. Many thanks to IRRI for providing monogenic line rice seeds.

\section{References}

[1] Khush, G. S. 2005. "What It Will Take to Feed 5.0 Billion Rice Consumers in 2030.” Plant Molecular Biology 59 (1): 1-6.

[2] Ou, S. H. 1980. "Pathogen Variability and Host Resistance in Rice Blast Disease.” Аnnu. Rev. Phytopathol. 18: 167-87.

[3] Valent, B. 1990. "Rice Blast as a Model System for Plant Pathology.” Phytopathology 80 (1): 33-6.

[4] Cruz-Vazquez, C., Ramos-Parra, M., Itela-Mendoza, I., Garcia-Vazquez, Z., and Quintero-Martinez, M. T. 2007. "Relationships between Stable Fly Infestation with Some Physical Facility Characteristics and Sanitation Practices in Several Dairy Farms in the State of Aguascalientes, Mexico.” Vet. Parasitol. 149 (3-4): 246-50.

[5] Webster, R. K., and Gunnell, P. S. 1992. Compendium of Rice Diseases. St. Paul, MN: American Phytopathological Society.

[6] Silue, D., Notteghem, D. J., and Tharreau, D. 1992. "Evidence for the Gene for Gene Relationship in the Oryza sativa-Magnaporthe grisea Pathosystem." Phytopath. 82 (5): 577-80.

[7] Long, D. H., Lee, F. N., and TeBeest, D. O. 2000. "Effect of Nitrogen Fertilization on Disease Progress of Rice Blast on Susceptible and Resistant Cultivars.” Plant Disease 84 (4): 403-9.

[8] TeBeest, D. O., Guerber, C., and Ditmore, M. 2007. "Rice Blast." The Plant Health Instructor. The American Phytopathological Society. Accessed March, 2007. http://www.apsnet.org/edcenter/intropp/lessons/fungi/asc omycetes/Pages/RiceBlast.aspx.

[9] Ou, S. H. 1995. Rice Diseases, 2nd ed.. Kew, England: Commonwealth Mycological Institute, 380.

[10] Bonman, J. M., Khush, G. S., and Nelson, R. J. 1992. "Breeding Rice for Resistance to Pests." Ann. Rev. Phytopathology 30: 507-28.

[11] Sharma, T. R., Rai, A. K., Gupta, S. K., Vijayan, J., Devanna, B. N., and Ray, S. 2012. "Rice Blast Management through Host-Plant Resistance: Retrospect and Prospects.” Agric. Res. 1 (1): 37-52.

[12] Koide, Y., Telebanco-Yanoria, M. J., Peña, F. D., Fukuta, Y., and Kobayashi, N. 2011. "Characterization of Rice Blast Isolates by the Differential System and Their Application for Mapping Resistance Gene, Pi19(t).” J. Phytopathol. 159 (2): 85-93.

[13] RoyChowdhury, M., Jia, Y., Jackson, A., Jia, M. H., Fjellstrom, R., and Cartwright, R. D. 2012. “Analysis of Rice Blast Resistance Gene Pi-z in Rice Germplasm Using Pathogenictiy Assays and DNA Markers.” Euphytica 184 (1): 35-46.

[14] Lau, G. W., and Ellingboe, A. H. 1993. "Genetic Analysis of Mutations to Increased Virulence in Magnaporthe grisea.” Phytopathology 83 (10): 1093-6.

[15] Kiyosawa, S. 1982. "Genetics and Epidemiological Modeling of Breakdown of Plant Disease Resistance.” Annual Review of Phytopathology 20: 93-117.

[16] Bonman, J. M., and Mackill, D. J. 1988. "Durable Resistance to Rice Blast Disease.” Oryza 25: 103-10.

[17] Chen, Q. H., Wang, Y. C., and Zheng, X. B. 2006. "Genetic Diversity of Magnaporthe grisea in China as Revealed by DNA Fingerprint Heliotypes and Pathotypes.” Phytopathology 154 (6): 361-9.

[18] Jia, Y., and Moldenhauer, K. 2010. "Development of Monogenic and Digenic Rice Lines for Blast Resistance Genes Pi-ta, Pi-kh/Pi-ks.” J. Plant Regist. 4 (2): 163-6.

[19] Atkins, J. G., Robert, A. L., Adair, C. R., Goto, K., Kozaka, T., Yanagida, R., Yamada, M., and Matsumoto, S. 1967. "An International Set of Rice varieties for Differentiating Races of Pyricularia oryzae.” Phytopathology 57: 297-301.

[20] Mackill, D. J., and Bonman, J. M. 1992. "Inheritance of Blast Resistance in Near-Isogenic Lines of Rice.” Phytopathology 82 (7): 746-9.

[21] Ling, Z. Z., Mew, T. W., Wang, J. L., Lei, C. L., and Huang, N. 2001. "Development of Chinese Near Isogenic Lines of Rice and Their Differentiating Ability of Pathogenic Races of Blast Fungus.” Chin. Agric. Sci. 1: 50-6.

[22] Telebanco-Yanoria, M. J., Ohsawa, R., Senoo, S., Kobayashi, N., and Fukuta, Y. 2008. "Diversity Analysis 

Lines under Field Condition and Pathogenicity Assays

for Resistance of Rice (Oryza sativa L.) to Blast Disease (Magnaporthe grisea (Hebert) Barr.) Using Differential Isolates from the Philippines.” Plant Breed. 127 (4): 355-63.

[23] Wang, J. C., Jia, Y., Wen, J. W., Liu, W. P., Liu, X. M., Li, L., Zhang, J. H., Jiang, Z. Y., Guo, X. L., and Ren, J. P. 2013. "Identification of Rice Blast Resistance Genes Using International Monogenic Differentials.” Crop Prot. 45: 109-16.

[24] Le, M. T., Tsutomu, A., and Tohru, T. 2010. "Population Dynamics and Pathogenic Races of Rice Blast Fungus, Magnaporthe oryzae in the Mekong Delta in Vietnam.” J. Gen. Plant Pathol. 76 (3): 177-82.

[25] Bureau of Statistics, Ministry of Agriculture and Rural Development (MARD). 2013. Statistical Yearbook. Vietnam: MARD.

[26] International Rice Research Institute (IRRI). 1996. Standard Evaluation System for Rice. Genetic Resources Centre, Manila, Philippines.

[27] Das, M. K., Rajaram, S., Mundt, C. C., and Kronstad W.
E. 1992. "Inheritance of Slow Rusting Resistance to Leaf Rust in Wheat.” Crop Sci. 32 (6): 1452-6.

[28] Filippi, M. C., and Prabhu, A. S. 2001. "Phenotypic Virulence Analysis of Isolates from Brazilian Upland Rice Cultivars.” Pesqu Agropecu Bras 36 (1): 27-35.

[29] Berruyer, R., Adreit, H., Milazzo, J., Gaillard, S., Berger, A., Dioh, W., Lebrun, M. H., and Tharreau, D. 2003. "Identification and Fine Mapping of Pi33, the Rice Resistance Gene Corresponding to the Magnaporthe grisea Avirulence Gene ACE1.” Theor. Appl. Genet. 107 (6): 1139-47.

[30] Bastiaans, L. 1991. "Ratio between Virtual and Visual Lesion Size as a Measure to Describe Reduction in Leaf Photosynthesis of Rice Due to Leaf Blast.” Phytopathology 81 (6): 611-5.

[31] Bonman, J. M. 1992. "Durable Resistance to Rice Blast Disease: Environmental Influences.” Euphytica 63 (1): 115-23.

[32] Flor, H. H. 1971. "Current Status of the Gene-for-Gene Concept.” Ann. Rev. Phytopath. 9: 275-96. 